Abstracta Iranica

Revue bibliographique pour le domaine irano-aryen

Volume 42-43 | 2021

Comptes rendus des publications de 2019-2020

\title{
Manata Hashemi. Coming of Age in Iran: Poverty and the Struggle for Dignity
}

\section{Stella Morgana}

\section{(2) OpenEdition \\ 1 Journals}

\section{Electronic version}

URL: https://journals.openedition.org/abstractairanica/52935

DOI: 10.4000/abstractairanica.52935

ISSN: 1961-960X

Publisher:

CNRS (UMR 7528 Mondes iraniens et indiens), Éditions de l'IFRI

\section{Electronic reference}

Stella Morgana, "Manata Hashemi. Coming of Age in Iran: Poverty and the Struggle for Dignity", Abstracta Iranica [Online], Volume 42-43 | 2021, document 4, Online since 30 July 2021, connection on 14

December 2022. URL: http://journals.openedition.org/abstractairanica/52935 ; DOI: https://doi.org/

$10.4000 / a b s t r a c t a i r a n i c a .52935$

This text was automatically generated on 14 December 2022.

All rights reserved 
Manata Hashemi. Coming of Age in Iran: Poverty and the Struggle for Dignity

Stella Morgana 


\section{REFERENCES}

Manata Hashemi. Coming of Age in Iran: Poverty and the Struggle for Dignity. New York: New York University Press, 2020, 256 pp.

1 If one had to choose one book to study the youth in Iran and get insightful glimpses of ordinary life, Manata Hashemi's work offers an invaluable resource to start with. Coming of Age in Iran: Poverty and the Struggle for Dignity zooms out at the lives of young Iranians aged 15-29, whose households' income barely stands at the minimum wage. Building on extensive fieldwork conducted in Iran over the period between 2008 and 2019, this book sheds light on the lives of the young poor. It navigates the youth coping strategies with hardship, as well as social acceptance. In each of its five chapters, Hashemi's study brings the reader on a journey into the lives of those who strive to define their dignity between social constructions, validation and stigma.

2 The forty-four interviews collected in the book show the poor districts of south Tehran and Sari, the capital city of the northern Mazandaran province, through the lens of the so-called "face-savers." These are the young people who manage to comply with the standards imposed by their community while renegotiating patterns of morality and avoiding to show their poverty. Hashemi describes the "face game" as based on the following components: self-sufficiency, responsibility, hard work, purity. Whereas the tension between conformity and dignity is at the core of this engaging study through the prism of individual empowerment, the collective element of the struggle against economic deprivation remains in the background.

\section{AUTHORS}

\section{STELLA MORGANA}

University of Amsterdam 